\title{
The Role of NKL Homeobox Genes in T-Cell Malignancies
}

\author{
Stefan Nagel (1)
}

check for updates

Citation: Nagel, S. The Role of NKL

Homeobox Genes in T-Cell Malignancies. Biomedicines 2021, 9 , 1676. https://doi.org/10.3390/ biomedicines 9111676

Academic Editors: Danilo Fiore and Luca Vincenzo Cappelli

Received: 30 September 2021 Accepted: 10 November 2021 Published: 12 November 2021

Publisher's Note: MDPI stays neutral with regard to jurisdictional claims in published maps and institutional affiliations.

Copyright: (C) 2021 by the author. Licensee MDPI, Basel, Switzerland. This article is an open access article distributed under the terms and conditions of the Creative Commons Attribution (CC BY) license (https:/ / creativecommons.org/licenses/by/ $4.0 /)$.
Department of Human and Animal Cell Lines, Leibniz-Institute DSMZ, 38124 Braunschweig, Germany; sna@dsmz.de; Tel: +49-531-2616-167

\begin{abstract}
Homeobox genes encode transcription factors controlling basic developmental processes. The homeodomain is encoded by the homeobox and mediates sequence-specific DNA binding and interaction with cofactors, thus operating as a basic regulatory platform. Similarities in their homeobox sequences serve to arrange these genes in classes and subclasses, including NKL homeobox genes. In accordance with their normal functions, deregulated homeobox genes contribute to carcinogenesis along with hematopoietic malignancies. We have recently described the physiological expression of eleven NKL homeobox genes in the course of hematopoiesis and termed this gene expression pattern NKL-code. Due to the developmental impact of NKL homeobox genes these data suggest a key role for their activity in the normal regulation of hematopoietic cell differentiation including T-cells. On the other hand, aberrant overexpression of NKL-code members or ectopical activation of non-code members has been frequently reported in lymphoid and myeloid leukemia/lymphoma, demonstrating their oncogenic impact in the hematopoietic compartment. Here, we provide an overview of the NKL-code in normal hematopoiesis and discuss the oncogenic role of deregulated NKL homeobox genes in T-cell malignancies.
\end{abstract}

Keywords: homeobox; homeodomain; NKL-code; T-all; lymphoma

\section{T-Cell Development}

All blood and immune cells are classified as lymphoid or myeloid and generated by hematopoietic stem cells (HSC) which reside in the bone marrow. The lymphoid lineage begins with the HSC-derived common lymphoid progenitor (CLP). The panel of mature lymphoid cell types generated in the course of lymphopoiesis includes B-cells, T-cells, NK-cells and innate lymphoid cells (ILCs). T-cells derive from early T-cell progenitors (ETP) which migrate from the bone marrow into the thymus to terminate their basic differentiation. Intermediate stages of developing T-cells are phenotypically distinguished by their surface markers CD4 and CD8 and accordingly called double negative (DN), double positive (DP) and single positive (SP) thymocytes. The thymic differentiation processes result in naïve T-cells, possessing selected T-cell receptors able to detect non-self antigens. Further differentiation of T-cells takes subsequently place in extrathymic tissues.

These fundamental T-cell differentiation processes are mainly regulated at the transcriptional level [1,2]. Accordingly, several hematopoietic and T-cell specific transcription factors (TF) are reported which control the progression of T-cell development. Frequently, their deregulation and mutation underlie the generation of T-cell malignancies $[1,3,4]$. Therefore, the knowledge and functional understanding of normal and aberrant activities of T-cell specific TFs may help to diagnose and treat T-cell leukemias and lymphomas.

\section{NKL Homeobox Genes in Normal and Malignant T-Cells \\ 2.1. Classification of Homeobox Genes}

TFs are classified according to similarities in sequence and structure. Homeobox genes encode one of the largest groups of TFs in the human genome [5]. Generally, they regulate basic development and differentiation in both embryogenesis and adulthood. These genes share the conserved homeobox which is $180 \mathrm{bp}$ long and encodes the homeodomain at 
the protein level. This domain consists of 60 amino acid residues which form three helices, generating a specific 3D structure of the helix-turn-helix type. The homeodomain performs specific interactions with DNA, chromatin, non-coding RNAs and cooperating TFs, thus representing the core of their gene regulatory activities [6]. Specific DNA contacts are realized by helix 3 which fits into the major groove [7]. The remaining helices stabilize the domain structure and, together with flanking amino acid residues, allow additional DNA interactions.

From the systematic classification of all 235 human homeobox genes emerged a panel of eleven classes and several subclasses. The main classes are called antennapedia (ANTP) and paired box (PRD). Other classes identified are CERS, CUT, HNF, LIM, POU, PROS, SINE, TALE, and ZF. According to this system, NKL homeobox genes represent a subclass of the ANTP class and number 48 members in humans [8].

Nirenberg and Kim (abbreviated as NK) were the first who reported in the fruit fly Drosophila NK-like homeobox genes which were later summarized as NKL. In this developmental model organism, the NKL subclass members are arranged in a cluster consisting of six genes [9]. Additional orthologous genes were later identified, extending this group of genes. Comparative genome analyses revealed this clustering to be the ancient gene order which remains barely discernible in vertebrates [10]. Thus, human NKL homeobox genes show only relicts of a clustered arrangement while the HOX-genes are still present in a clustered order in both fruit fly and humans.

NKL proteins share a conserved homeodomain which displays the amino acid tyrosine at position 54 [11]. In addition, NKL homeodomain proteins contain a short conserved sequence in their N-terminal region which has been termed engrailed-homology motif (EH1) [12]. This EH1 sequence mediates physical interactions with corepressors of the Groucho-family (transducin-like enhancer of split, TLE), thus transforming NKL homeodomain factors into transcriptional repressors [13] (Figure 1). Most NKL homeobox genes are involved in mesodermal development, possibly recapitulating their ancient functions, including repression of alternative differentiation lineages [14,15]. Many NKL homeobox genes operate as master factors, further demonstrating the regulatory and developmental potential of these genes. For example, NKX2-5 controls the development of the spleen and heart, and NKX2-1 that of lungs and the thyroid gland [16,17].

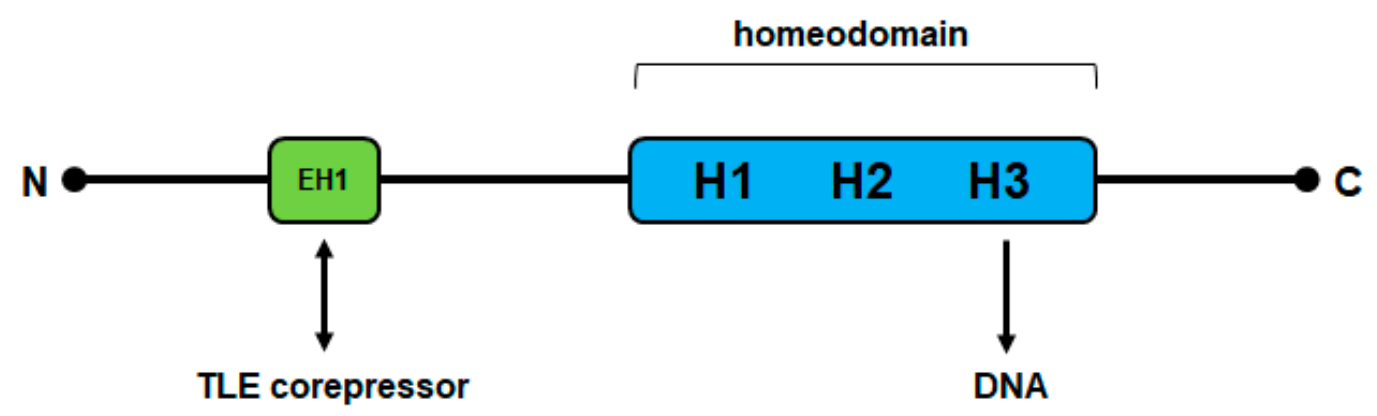

Figure 1. Schematic structure of NKL homeodomain proteins. N: N-terminal end; C: C-terminal end; EH1: conserved engrailed homology domain consisting of about 8 amino acid residues (shown in green); the conserved homeodomain consists of 60 amino acid residues which generate three helices $(\mathrm{H} 1, \mathrm{H} 2, \mathrm{H} 3)$ and is shown in blue; the $\mathrm{N}$ - and C-terminal parts show no sequence conservation. The EH1 domain and the homeodomain interact with particular components of the gene regulatory machinery including corepressors of the TLE family and specific DNA sequences, respectively.

\subsection{NKL-Code in Hematopoiesis}

In several studies, we examined the physiological expression pattern of NKL homeobox genes in stem cells, intermediate progenitors and terminally differentiated blood and immune cells across the whole hematopoietic system. The lymphoid lineage was analyzed in four studies using public datasets of developing and mature T-cells, B-cells, NK-cells and ILCs [18-21]. Datasets covering the myeloid lineage were analyzed in two studies [22,23]. 
The accumulated results are summarized in Figure 2, showing specific NKL homeobox gene activities in distinct hematopoietic stages and cell types. Altogether, eleven NKL homeobox genes were identified, comprising DLX2, HHEX, HLX, HMX1, MSX1, NANOG, NKX2-3, NKX3-1, NKX6-3, TLX2 and VENTX. Their unique expression pattern has been termed NKL-code $[18,24]$.

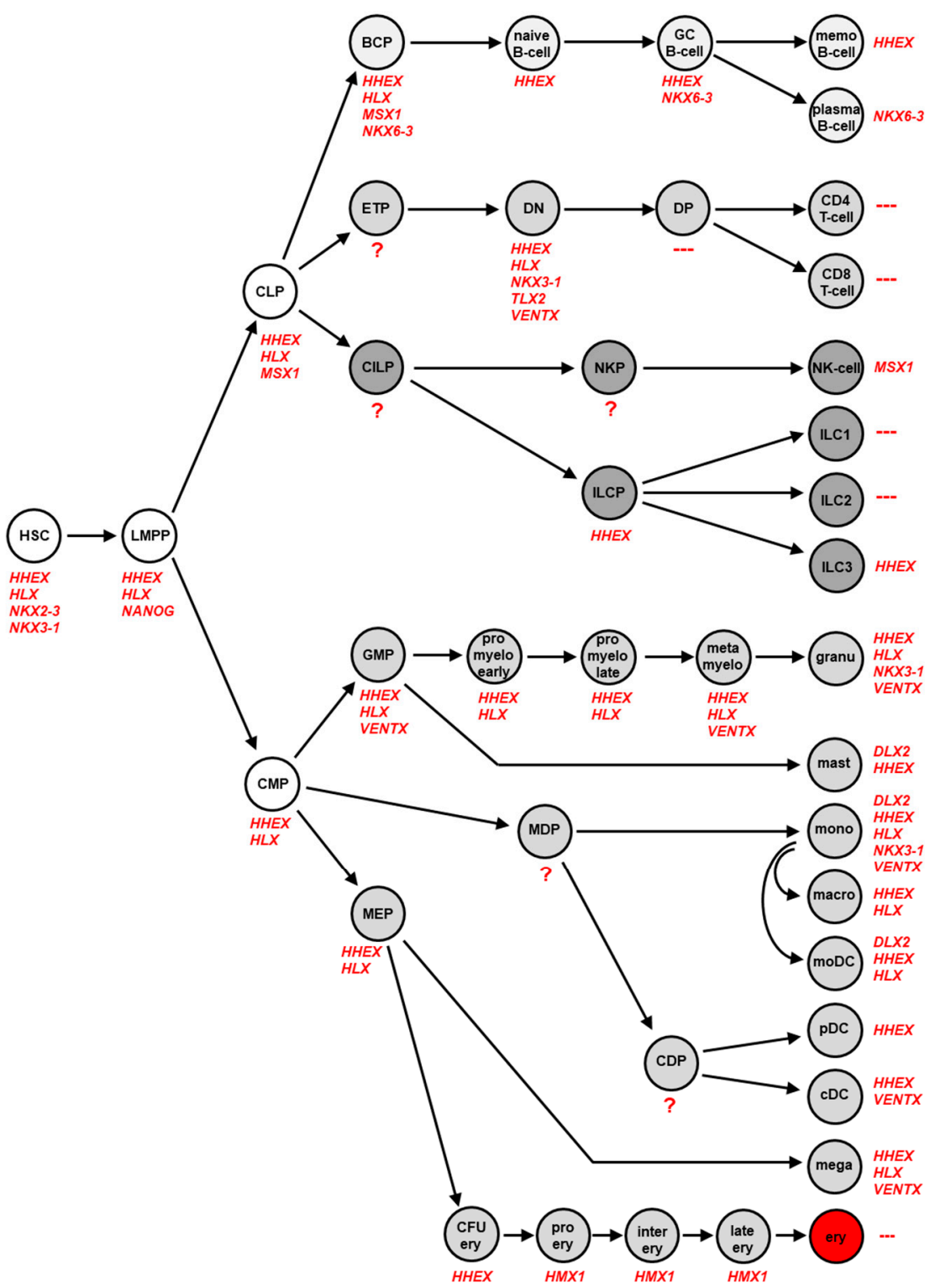

Figure 2. The NKL-code in lymphopoiesis This diagram depicts activities of NKL homeobox genes during early hematopoiesis, in lymphopoiesis including development of T-cells, B-cells, NK-cells and ILCs, and in myelopoiesis. Each cell-type/stage is labelled with the accordingly expressed NKL homeobox genes. BCP: B-cell progenitor, $\mathrm{CDC}$ : conventional dendritic cell, CDP: common dendritic progenitor, CILP: common innate lymphoid progenitor, CLP: common lymphoid progenitor, CMP: common myeloid progenitor, DN: double negative, DP: double positive, ETP: early T-cell progenitor, GC B-cell: germinal center B-cell, GMP: granulocytic-monocytic progenitor, HSC: hematopoietic stem cell, ILC(P): innate lymphoid cell (progenitor), LMPP: lymphoid and myeloid primed progenitor, memo B-cell: memory B-cell, MEP: megakaryocyte-erythroid-progenitor, pDC: plasmacytoid dendritic cell. ?: no expression data were available for progenitor stages CLP, NKP, MDP and CDP, ---: no NKL homeobox gene activity detectable.

The most prominent representatives of the NKL-code are HHEX and HLX active in HSC, multiple progenitors, and various mature blood cells. In contrast, the expression of 
NKX2-3 and NANOG is restricted to the earliest stages of hematopoiesis, including HSC and lymphoid and myeloid primed progenitors (LMPP), respectively. NKX6-3 is just expressed in the B-cell lineage, TLX2 in the DN-stage of T-cell development, DLX2 in mature mast cells and monocytes, and HMX1 in the course of erythropoiesis. MSX1 is expressed in CLP and in NK-cells. NKX3-1 shows a diverse expression pattern comprising undifferentiated HSC and DN T-cells in addition to differentiated granulocytes and monocytes. Recently, VENTX expression was described in progenitor-derived conventional dendritic cells (DC) while silent in plasmacytoid DC [23]. Of note, VENTX is also expressed at the DN stage of developing T-cells [18]. An absence of NKL homeobox gene activity was found for DP, CD4 and CD8 SP T-cells and for ILC1 and ILC2. Thus, in contrast to these lymphoid cell types remaining hematopoietic cells specifically express one or several members of the NKL homeobox gene subclass. DN T-cells express five different NKL homeobox genes while mature T-cells are silent for all subclass members. This observation may indicate that accurately controlled activity of NKL homeobox genes plays an important role in developing T-cells which are, therefore, prone to malignant transformation when these genes are deregulated.

Of note, some screenings for gene activities in these various hematopoietic cell types were conducted by expression profiling. The used standard gene chips do not contain the complete panel of known human genes and lack eleven NKL homeobox genes. However, analysis of RNA-seq data generated from various hematopoietic stem and progenitor cells confirmed inactivity of these eleven genes in immature stages [25], supporting the integrity of the described NKL-code.

These findings were promoted by data reported for particular NKL homeobox genes and hematopoietic cell types. HLX and HHEX represent the first described non-HOX homeobox genes expressed in hematopoietic cells [26,27]. Expression analyses of both genes revealed activity in B- and myeloid cells while T-cells tested negative [26,28-30]. Moreover, downregulation of HHEX was shown to be crucial for normal T-cell differentiation and its activity absent in plasma cells [30]. Analysis of HHEX-knockout mice showed disturbed development of all types of lymphocytes, demonstrating the importance of HHEX for lymphopoiesis [31]. Recently, a role of HHEX was shown in the development of memory B-cells, supporting its reported expression according to the NKL-code [19,32]. Forced expression of HLX in hematopoietic progenitors enhanced myeloid differentiation but arrested the development of B-cells at the pro-B-cell stage and of T-cells at the DP stage, highlighting the shutdown of its activity for lymphocyte maturation $[28,33]$. NKL homeobox genes HHEX, NKX6-3 and VENTX have been analyzed for their physiological regulation in hematopoiesis $[19,23,34]$. The data show that these genes are controlled by known hematopoietic master factors and thus part of lineage-specific gene networks.

Homeobox genes regulate basic processes in tissue and organ development. This potential, in addition to specific activities of closely related homeobox genes, has been referred to by the annotation of codes. The HOX-code describes the ordered expression of the clustered HOX genes along the anterio-posterio axis of the developing hindbrain and of the embryonal pharynx [35,36]. The DLX-code addressed the expression pattern of DLX genes along the dorsal-ventral axis in the pharyngeal region of the embryo [37]. The identity of the developing placodes which generate different sensory organs is manifested by the expression of particular PAX genes and, accordingly, termed PAX-code [38]. Finally, the TALE-code defines a signature of TALE class homeobox genes in lymphopoiesis [39]. Thus, the NKL-code along with other homeobox gene codes serves to outline and understand developmental gene activities and their subordinate differentiation processes.

\subsection{Deregulated NKL Homeobox Genes in T-Cell Acute Lymphoid Leukemia}

In cell and tissue differentiation, specific intermediate stages are distinguishable. In cancer, normal progression is disturbed and developmental arrest at particular immature stages is a dominant and widespread feature of malignant cells [40-42]. Thus, cancer may represent a developmental disease. Accordingly, forced expression of NKL homeobox gene 
HLX in hematopoietic progenitors resulted in the developmental arrest of pro-B-cells [33]. This experiment was the first hint for the oncogenic potential of NKL homeobox genes in hematopoietic cells. Later, Ferrando and coworkers described the aberrant expression of NKL homeobox gene TLX1 at the DP stage in T-cell acute lymphoid leukemia (TALL), indicating that this gene specifically promotes developmental arrest of malignant thymocytes [4]. The strong correlation of aberrantly expressed NKL homeobox genes with particular stages of lymphoid differentiation highlights the developmental potency of these genes in hematopoietic tumors.

Table 1. Aberrantly expressed NKL homeobox genes in T-cell leukemia/lymphoma patients and cell lines.

\begin{tabular}{|c|c|c|c|c|c|c|c|c|c|}
\hline Gene & AITL & ALCL & ATLL & HSTL & NKTI & PTCL & T-ALL & T-Cell Line Models & References \\
\hline BARHL1 & & & & & & & + & & \\
\hline \multicolumn{10}{|l|}{ BARHL2 } \\
\hline \multicolumn{10}{|l|}{$B A R X 1$} \\
\hline$B A R X 2$ & & & & & & & + & & \\
\hline \multicolumn{10}{|l|}{$B S X$} \\
\hline \multicolumn{10}{|l|}{$D B X 1$} \\
\hline \multicolumn{10}{|l|}{$D B X 2$} \\
\hline$D L X 1$ & & & & & & & + & & \\
\hline$D L X 2$ & & & & & & & + & HPB-ALL & [43] \\
\hline$D L X 3$ & & & & & & & + & & \\
\hline$D L X 4$ & & & & & + & & & & \\
\hline \multicolumn{10}{|l|}{ DLX5 } \\
\hline$D L X 6$ & & & & & & & + & & \\
\hline \multicolumn{10}{|l|}{$E M X 1$} \\
\hline$E M X 2$ & & & & & & & + & & \\
\hline EN1 & & & & & & + & & & \\
\hline EN2 & & & & & & + & & & \\
\hline HHEX & + & + & + & + & + & + & + & CCRF-CEM, RPMI-8402 & [43] \\
\hline$H L X$ & + & + & + & + & + & + & + & DEL, KI-JK, L-82, SR-786, SU-DHL-1, SUP-M2 & [21] \\
\hline \multicolumn{10}{|l|}{$H M X 1$} \\
\hline$H M X 2$ & & & & & + & & & & \\
\hline \multicolumn{10}{|l|}{$H M X 3$} \\
\hline$L B X 1$ & & & & & & & + & & \\
\hline$L B X 2$ & & & & & & & + & & \\
\hline MSX1 & + & + & + & + & & + & + & DERL-2, DERL-7, LOUCY & {$[44,45]$} \\
\hline$M S X 2$ & & & & & & & + & & \\
\hline NANOG & & & & & + & & & & \\
\hline NKX1-1 & + & + & & & & + & + & & \\
\hline \multicolumn{10}{|l|}{ NKX1-2 } \\
\hline$N K X 2-1$ & + & + & + & & & + & + & RPMI-8402 & [43] \\
\hline NKX2-2 & + & + & + & & & + & + & & \\
\hline NKX2-3 & + & + & + & + & + & + & + & & \\
\hline NKX2-4 & & & & & & & & & \\
\hline
\end{tabular}


Table 1. Cont.

\begin{tabular}{|c|c|c|c|c|c|c|c|c|c|}
\hline Gene & AITL & ALCL & ATLL & HSTL & NKTL & PTCL & T-ALL & T-Cell Line Models & References \\
\hline NKX2-5 & & + & & + & + & + & + & CCRF-CEM, PEER & [46] \\
\hline \multicolumn{10}{|l|}{ NKX2-6 } \\
\hline \multicolumn{10}{|l|}{ NKX2-8 } \\
\hline NKX3-1 & & & & & + & & + & JURKAT, MOLT-4, RPMI-8402 & [47] \\
\hline NKX3-2 & & & & & & & + & CCRF-CEM & [48] \\
\hline NKX6-1 & & + & & & & + & & & \\
\hline \multicolumn{10}{|l|}{ NKX6-2 } \\
\hline NKX6-3 & & & & & + & & + & & \\
\hline \multicolumn{10}{|l|}{ NOTO } \\
\hline$T L X 1$ & & & & + & & & + & ALL-SIL & [49] \\
\hline$T L X 2$ & & & & & & & + & & \\
\hline$T L X 3$ & & & & & + & & + & DND-41, HPB-ALL & [50] \\
\hline \multicolumn{10}{|l|}{$V A X 1$} \\
\hline$V A X 2$ & & & & & + & & & & \\
\hline \multicolumn{10}{|l|}{ VENTX } \\
\hline 48 & 7 & 9 & 6 & 6 & 11 & 11 & 25 & & \\
\hline
\end{tabular}

This table lists all 48 NKL homeobox genes and shows deregulated subclass members in defined T-cell malignancies. (marked with " $+")$. NKL-code members are indicated in red letters, genes not represented on standard expression arrays are indicated in blue letters. Angioimmunoblastic T-cell lymphoma (AITL), anaplastic large cell lymphoma (ALCL), adult T-cell leukemia/lymphoma (ATLL), hepatosplenic T-cell lymphoma (HSTL), NKT-cell lymphoma (NKTL), peripheral T-cell lymphoma (PTCL), and T-cell acute lymphoid leukemia (T-ALL). NKL-positive T-cell malignancies are marked with " + ".

The NKL-code allows the evaluation of NKL homeobox gene activities in hematopoietic malignancies. Table 1 summarizes reported deregulated NKL homeobox genes identified in T-cell malignancies, including angioimmunoblastic T-cell lymphoma (AITL), anaplastic large cell lymphoma (ALCL), adult T-cell lymphoma (ATLL), hepatosplenic T-cell lymphoma (HSTL), natural killer T-cell leukemia/lymphoma (NKTL), peripheral T-cell lymphoma (PTCL) and T-ALL [44]. Together, 32 aberrantly expressed genes of the 48 gene strong NKL homeobox gene subclass have been described in these cancers, demonstrating their ubiquity and oncogenic impact in the T-cell compartment. Despite their relatively recent discovery, NKL homeobox genes form the most substantial group of oncogenes in leukemia and lymphoma. With few exceptions, most deregulated NKL homeobox genes are expressed in both lymphoid and myeloid malignancies. As analyzed so far, aberrantly expressed NKL homeobox genes show no mutations in their coding regions. Mutations in non-coding regulatory regions have been reported for HMX2 and HMX3 in acute myeloid leukemia (AML), highlighting transcriptional deregulation as a main pathological cause [51]. The following account summarizes deregulating mechanisms and oncogenic functions of selected NKL homeobox genes hitherto described in T-ALL.

\subsubsection{TLX1}

In 1991, investigation of chromosomal rearrangement $\mathrm{t}(10 ; 14)(\mathrm{q} 24 ; \mathrm{q} 11)$ in T-ALL patients by the group of Stanley Korsmeyer demonstrated juxtaposition of T-cell receptor gene $T R D$ and T-cell leukemia homeobox 1 (TLX1, formerly HOX11) [49]. Since then, aberrantly activated TLX1 emerged as a hallmark oncogene for this malignancy, although TLX1 is expressed in merely $10 \%$ of pediatric and $30 \%$ of adult T-ALL patients [50]. Retrospectively, TLX1 was the first NKL homeobox gene reportedly deregulated in hematopoietic malignancies. Normally, TLX1 plays a fundamental role in early spleen development, though it is not expressed in hematopoietic cells [52]. Therefore, TLX1 may perform to some extent its oncogenic function by reactivation of embryonal splenic activities. 


\subsubsection{TLX3}

In 2001, the group of Roger Berger reported a novel cryptic translocation, $t(5 ; 14)(\mathrm{q} 35 ; \mathrm{q} 32)$, in T-ALL subsets. This aberration activates T-cell leukemia homeobox 3 (TLX3, formerly HOX11L2) by juxtaposition to the BCL11B locus and was detected in about $25 \%$ of pediatric and 5\% of adult T-ALL patients [53]. Despite their high similarity, TLX1- and TLX3-rearranged T-ALL patients show different prognoses [54]. Functionally, T-cell differentiation factor $B C L 11 B$ is downregulated by chromosomal juxtaposition with TLX3 or directly by TF TLX1 [55], highlighting its tumor suppressor activity in T-ALL. Furthermore, TLX1 and TLX3 interact with TF ETS1 in T-ALL cells, thereby blocking TCR-rearrangement and T-cell differentiation [56]. Another gene family member, TLX2 (HOX11L1), though physiologically expressed in T-cell progenitors, is only rarely deregulated in T-ALL [18].

\subsubsection{NKX2-5}

In 2003, we reported an alternative, cytogenetically identical $t(5 ; 14)(q 35 ; \mathrm{q} 32)$ in two T-ALL cell lines which juxtaposes BCL11B with NK2 homeobox 5 (NKX2-5, formerly CSX1) [46]. This indicative finding helped us to uncover the wider oncogenic role of NKL homeobox genes in T-ALL, then comprising TLX1, TLX3 and NKX2-5. Today, 24 deregulated NKL homeobox genes are described in T-ALL, supporting the importance of this group of oncogenes for this disease [18,57]. However, NKX2-5 is rarely expressed in this malignancy $[18,58]$. Normally, NKX2-5 plays a key physiological role in the development of the spleen and heart $[16,51]$. Uniting its physiological and leukemic roles, myocyte-specific enhancer factor 2C (MEF2C) has been shown to serve as a target gene of NKX2-5 in both heart and leukemic T-cells [59,60]. MEF2C itself has, meanwhile, emerged as a major oncogene in T-ALL, alternatively activated by chromosomal deletion and translocation, or by other deregulated transcription factors [60-62].

\subsubsection{NKX2-1}

In T-ALL, chromosomal translocation $\mathrm{t}(7 ; 14)(\mathrm{q} 34 ; \mathrm{q} 13)$ causes aberrant activation of NK2 homeobox 1 (NKX2-1) [61]. NKX2-1, like NKX2-2 and NKX2-5, activates MEF2C in T-ALL [61]. In addition, NKX2-1 is aberrantly activated in diffuse large B-cell lymphoma (DLBCL) where it is deregulated by an altered chromatin configuration instead of a chromosomal rearrangement [63]. Thus, the same NKL homeobox gene is aberrantly activated by diverse mechanisms in different lymphoid malignancies. Normally, NKX2-1 plays a role in the development of the lung and thyroid gland but is absent from hematopoietic cells and tissues [17].

\subsubsection{NKX2-3}

Recently, a cytogenetic screen for novel translocation partners of the TCR genes in T-ALL revealed targeted NKL homeobox gene NKX2-3 [57]. In the hematopoietic compartment, NKX2-3 is expressed only in HSCs [18]. Therefore, aberrant activation of this hematopoietic stem cell gene may deregulate or stop normal T-cell differentiation.

\subsubsection{NKX2-4}

Another cytogenetic screen for TCR translocation partners in T-ALL revealed juxtaposition to NKX2-4 [64]. This NKL homeobox gene is no NKL-code member and thus silent in hematopoietic cells. Normally, NKX2-4 is just expressed in the hypothalamus $[65,66]$. Its oncogenic role in T-cell malignancies is hitherto unclear.

\subsubsection{NKX3-1}

NK3 homeobox 1 (NKX3-1, formerly BAPX2) is hematopoietically expressed in stem cells and DN T-cell progenitors [18]. In T-ALL, NKX3-1 is aberrantly activated by the hematopoietic TFs TAL1 and GATA3 [47,67]. NKX3-1 expression correlates with oncogenic TAL1 activity and additionally with aberrant expression of homeobox gene SIX6 in T-ALL patients [68]. Consistently, SIX6 in turn is directly activated by NKX3-1 or alternatively by 
the closely related NKL-factor NKX3-2 (BAPX1) as described in both T-ALL patients and cell lines [47,48]. However, the leukemic role of SIX6 in T-ALL remains unclear.

\subsection{Deregulated NKL Homeobox Genes in T-Cell Lymphoma}

The oncogenic role of NKL homeobox genes was first described in T-ALL. Today, these genes are reportedly deregulated in all analyzed types of hematopoietic malignancies [24]. In the following, I summarize studies describing normal and aberrant activities of NKL homeobox genes which also play a role in T-cell lymphomas.

\subsubsection{DLX}

The human genome contains six Distal-less homeobox genes (DLX) which are arranged as neighboring pairs, sharing intergenic regulatory sites: DLX1 and DLX2, DLX3 and $D L X 4, D L X 5$ and DLX6 [69]. According to our NKL-code data, DLX2 represents the only hematopoietically expressed DLX gene in humans [24]. It is physiologically expressed just in mature myeloid cells, including mast cells, monocytes and monocyte-derived DCs [22]. $D L X 2$ is located at chromosomal position 2q31 next to its paralogue gene DLX1 which is normally silent in hematopoietic cells. However, expression of DLX1,DLX2 and DLX3 was reported in developing NK-cells of mice [70]. This particular stage was not included in the established NKL-code, requiring additional examinations in humans. Aberrant DLX gene expression has been shown for both DLX1 and DLX2 in T-ALL, AML and myelodysplastic syndrome (MDS) patients, showing divergent regulation in the malignant context $[18,22]$. In AML, oncogenic ERK-signalling drives the expression of both DLX1 and DLX2 [71]. In murine T-cell lymphoma, aberrant expression of neighboring DLX5 and DLX6 was correlated with inversion of chromosome 6, juxtaposing the loci of these NKL homeobox genes with T-cell receptor gene Tcrb [72]. DLX5 expression was also detected in primary human T-cell lymphoma samples while DLX6 tested negative [72]. Functionally, DLX5 promotes NOTCH-signalling and the AKT-pathway in a mouse model which may represent its main oncogenic function [73,74].

\subsubsection{HHEX}

Hematopoietically expressed homeobox gene (HHEX) is overexpressed in subsets of all analyzed T-cell malignancies [18,44]. However, our recent study demonstrates that HHEX acts like a tumor suppressor gene in ALCL cell lines. HHEX inhibits apoptosis and supports ILC3 differentiation. Potential target genes in these contexts are CASP8, FOXO3 and BHLHE40, respectively [21]. Of note, ILC3 physiologically expresses HHEX and may represent a cell of origin for ALCL [21,75]. Thus, HHEX may act as an oncogene or tumor suppressor gene in T-cell lymphomas.

\subsubsection{HLX}

H2.0 like homeobox (HLX) is overexpressed in several hematopoietic malignancies including ALCL, DLBCL and HL $[19,21]$. Aberrant activation by STAT3 plays a dominant role in HLX expression in these tumor types and represents a hallmark factor in ALCL [76]. Analyses of several ALCL cell lines revealed genomic gains of the STAT3 and HLX loci and demonstrated a direct activating impact of STAT3 in HLX expression. These data highlight $H L X$ as an important oncogene and STAT3-target in this malignancy [21]. The requirement of the nuclear localization of STAT3 for HLX activation has been shown in HL cell line L-540 [77]. The role of Epstein-Barr virus mediated activation of STAT3 in HLX expression was demonstrated in DLBCL cell line DOHH-2 [78]. Thus, several oncogenic mechanisms activating STAT3 and HLX have been described in hematopoietic malignancies.

\subsubsection{MSX1}

Muscle segment homeobox gene 1 (MSX1) is aberrantly expressed in several types of leukemia and lymphoma, including ALCL, HL, HSTL, mantle cell lymphoma (MCL) and T-ALL $[18,19,79]$. In the hematopoietic system, MSX1 is normally expressed in the CLP and 
mature NK-cells $[18,20]$. These expression patterns reflect its contrasting roles as oncogene in T-ALL and tumor suppressor in NK-cell leukemia [20,45]. In T-ALL, downregulated BMP-signalling pathway and upregulated chromatin-mediator AUTS2 have been reported as activating mechanisms for MSX1 expression [44,45,80]. In HSTL, MSX1 is activated by AUTS2 and PDGF-signalling, and repressed by BMP4-signalling. The latter pathway is inhibited via PDGF-signalling, thereby contributing to MSX1 activation [44]. Finally, MSX1 plays a major role in generation and development of neural crest cells [81], supporting its role as lineage regulator in stem/progenitor cells.

\subsubsection{NANOG}

NANOG is a stem cell factor in hematopoiesis as well as in the development of other tissue types [18,22,82]. In a transgenic mouse model, Das and colleagues showed that NANOG supported the oncogenic potential of MYC in the generation of T-cell lymphoma [83]. MYC in turn promotes the expression of NANOG, and both factors coregulate together with SOX2 particular target genes to drive self-renewal [83].

\subsubsection{NKX2-2}

NKX2-2 is ectopically expressed in several types of T-cell lymphoma including PTCL, AITL, ALCL and ATLL [X]. In HSTL cell lines DERL-2 and DERL-7 NKX2-2 is mutually activated by MSX1 [44]. NKX2-2 and the closely related NKX2-1 are aberrantly activated by chromosomal translocations in T-ALL while in DLBCL NKX2-1 expression is driven by an altered chromatin configuration $[61,63]$. Downstream activities have been analyzed in T-ALL, showing that NKX2-2, like NKX2-1 and NKX2-5, activate expression of the hematopoietic TF MEF2C $[60,61]$. Normally, NKX2-2 plays a role in the development of the brain and pancreas but is absent from hematopoietic cells and tissues [84,85].

Additional NKL homeobox genes deregulated in T-cell lymphoma patients are NKX2-3, NKX3-1, EN1, EN2, HMX2, NKX1-1, NKX2-1, NKX2-5, NKX6-1, TLX1, TLX3 and VAX2 [44]. To date, these genes have not been analyzed in more detail in this group of hematopoietic malignancies. Nevertheless, analyzed and described examples show that deregulated NKL homeobox genes play basic pathogenic roles in T-cell lymphomas, performing various oncogenic functions. Deregulating mechanisms reported in leukemia/lymphoma include chromosomal translocation, chromatin modifications, mutations in TF binding sites, altered DNA-methylation, and aberrant activities of particular TFs and signalling pathways like BMP, ERK, or NOTCH. Downstream effects of these genes are even more divers, including activation of specific TFs and micro RNAs, inhibitory interaction with cell type specific TFs, deregulation of differentiation markers and signalling pathways, in addition to disturbed proliferation, apoptosis and differentiation [24]. Notably, ectopically expressed NKL homeobox genes highlight the role of activated alternative developmental processes for this group of oncogenes. The NKL-code and its oncogenic violation discloses an underlying pathological principle and the list of oncogenic activities performed by deregulated NKL homeobox genes comprises all characteristics described for tumorigenesis [24].

\subsection{Tumor Cell Lines as Models for Deregulated NKL Homeobox Genes}

Tumor cell lines are clonal cells that grow unlimited in culture. They are genomically stable, survive freezing and thawing, and are available for all investigators from cell line banks. Their genomic, epigenomic and transcriptional characteristics correlate to their cell of origin. Therefore, tumor cell lines represent suitable experimental models for that tumor type from which they were derived. Therefore, it is of fundamental importance to use authenticated and well-characterized cell lines to be able to transfer cell line data to particular cancers. In the literature evaluated and systematically listed hematopoietic cell lines have been described which meet these criteria and include the T-cell lymphoma type ALCL in addition to other tumor entities like AML, chronic myeloid leukemia, Bcell precursor ALL, double-hit B-cell lymphomas, HL, MDS, multiple myeloma, NK-cell leukemia, primary effusion lymphoma and primary mediastinal B-cell lymphoma [86-97]. 
Recently, we have generated exomes and transcriptomes for 100 leukemia/lymphoma cell lines, providing highly comparative sequence data for a large panel of hematopoietic tumor entities including T-cell malignancies [43]. These data may help to identify novel genes and their regulatory connections involved in the pathogenesis of particular tumor types.

Deregulated NKL homeobox genes were usually first ascertained in patients and subsequently investigated experimentally in cell lines to reveal mechanisms of deregulation and downstream activities. Table 1 shows T-cell lines which aberrantly express particular NKL homeobox genes. They may serve as models to study upstream and downstream factors of those deregulated NKL homeo-oncogenes. To find novel models comprehensive expression data are required generated by gene expression profiling or RNA-sequencing of cell lines. Comparison with the NKL-code reveals ectopic activities of NKL homeobox genes. Aberrant expression of NKL-code members depends on the origin (lineage, stage) of the particular cell line. Overexpressed NKL-code members in accordance with their stage-specificity deserve corresponding controls for identification. Generally, there is a need for the establishment of additional hematopoietic cell lines including T-cell lines to cover described subtypes and variants of the tumors.

\section{Conclusions}

In summary, NKL homeobox genes are physiologically expressed in hematopoiesis in a unique and specific pattern which we have termed NKL-code. This code serves to identify and evaluate deregulated NKL homeobox genes in leukemia/lymphoma. Aberrant activities of these basic developmental regulators contribute to the generation of T-cell malignancies. The knowledge of their pathophysiological activity may support the design of improved diagnostics and novel therapies in the future. However, direct pharmacological targeting of TFs is generally difficult. Moreover, NKL homeobox genes impact fundamental processes in various tissues, anticipating strong side effects after treatment. Validated tumor cell lines represent suitable models to study the regulation and function of NKL homeobox genes in normal and malignant T-cells and may help to uncover suitable therapeutic targets.

Funding: This research received no external funding.

Institutional Review Board Statement: Not applicable.

Informed Consent Statement: Not applicable.

Conflicts of Interest: The authors declare no conflict of interest.

\section{References}

1. Rothenberg, E.V. Transcriptional control of early T and B cell developmental choices. Annu. Rev. Immunol. 2014, 32, 283-321. [CrossRef]

2. Yui, M.A.; Rothenberg, E.V. Developmental gene networks: A triathlon on the course to T cell identity. Nat. Rev. Immunol. 2014, 14, 529-545. [CrossRef]

3. Graux, C.; Cools, J.; Michaux, L.; Vandenberghe, P.; Hagemeijer, A. Cytogenetics and molecular genetics of T-cell acute lymphoblastic leukemia: From thymocyte to lymphoblast. Leukemia 2006, 20, 1496-1510. [CrossRef] [PubMed]

4. Ferrando, A.A.; Neuberg, D.S.; Staunton, J.; Loh, M.L.; Huard, C.; Raimondi, S.C.; Behm, F.G.; Pui, C.H.; Downing, J.R.; Gilliland, D.G.; et al. Gene expression signatures define novel oncogenic pathways in $\mathrm{T}$ cell acute lymphoblastic leukemia. Cancer Cell 2002, 1, 75-87. [CrossRef]

5. Vaquerizas, J.M.; Kummerfeld, S.K.; Teichmann, S.A.; Luscombe, N.M. A census of human transcription factors: Function, expression and evolution. Nat. Rev. Genet. 2009, 10, 252-263. [CrossRef]

6. Bürglin, T.R.; Affolter, M. Homeodomain proteins: An update. Chromosoma 2016, 125, 497-521. [CrossRef]

7. Gehring, W.J.; Müller, M.; Affolter, M.; Percival-Smith, A.; Billeter, M.; Qian, Y.Q.; Otting, G.; Wüthrich, K. The structure of the homeodomain and its functional implications. Trends Genet. 1990, 6, 323-329. [CrossRef]

8. Holland, P.W.; Booth, H.A.; Bruford, E.A. Classification and nomenclature of all human homeobox genes. BMC Biol. 2007, 5, 47. [CrossRef] [PubMed]

9. Kim, Y.; Nirenberg, M. Drosophila NK-homeobox genes. Proc. Natl. Acad. Sci. USA 1989, 86, 7716-7720. [CrossRef] [PubMed]

10. Pollard, S.L.; Holland, P.W. Evidence for 14 homeobox gene clusters in human genome ancestry. Curr. Biol. 2000, 10, 1059-1062. [CrossRef]

11. Harvey, R.P. NK-2 homeobox genes and heart development. Dev. Biol. 1996, 178, 203-216. [CrossRef] [PubMed]

12. Smith, S.T.; Jaynes, J.B. A conserved region of engrailed, shared among all en-, gsc-, Nk1-, Nk2- and msh-class homeoproteins, mediates active transcriptional repression in vivo. Development 1996, 122, 3141-3150. [CrossRef] [PubMed] 
13. Jennings, B.H.; Ish-Horowicz, D. The Groucho/TLE/Grg family of transcriptional co-repressors. Genome Biol. 2008, 9, 205. [CrossRef] [PubMed]

14. Garcia-Fernàndez, J. The genesis and evolution of homeobox gene clusters. Nat. Rev. Genet. 2005, 6, 881-892. [CrossRef] [PubMed]

15. Jagla, K.; Bellard, M.; Frasch, M. A cluster of Drosophila homeobox genes involved in mesoderm differentiation programs. Bioessays 2001, 23, 125-133. [CrossRef]

16. Lints, T.J.; Parsons, L.M.; Hartley, L.; Lyons, I.; Harvey, R.P. Nkx-2.5: A novel murine homeobox gene expressed in early heart progenitor cells and their myogenic descendants. Development 1993, 119, 419-431. [CrossRef]

17. Lazzaro, D.; Price, M.; de Felice, M.; Di Lauro, R. The transcription factor TTF-1 is expressed at the onset of thyroid and lung morphogenesis and in restricted regions of the foetal brain. Development 1991, 113, 1093-1104. [CrossRef] [PubMed]

18. Nagel, S.; Pommerenke, C.; Scherr, M.; Meyer, C.; Kaufmann, M.; Battmer, K.; MacLeod, R.A.; Drexler, H.G. NKL homeobox gene activities in hematopoietic stem cells, T-cell development and T-cell leukemia. PLoS ONE 2017, 12, e0171164. [CrossRef]

19. Nagel, S.; MacLeod, R.A.F.; Meyer, C.; Kaufmann, M.; Drexler, H.G. NKL homeobox gene activities in B-cell development and lymphomas. PLoS ONE 2018, 13, e0205537. [CrossRef]

20. Nagel, S.; Pommerenke, C.; Meyer, C.; Kaufmann, M.; MacLeod, R.A.F.; Drexler, H.G. NKL homeobox gene MSX1 acts like a tumor suppressor in NK-cell leukemia. Oncotarget 2017, 8, 66815-66832. [CrossRef]

21. Nagel, S.; Pommerenke, C.; MacLeod, R.A.F.; Meyer, C.; Kaufmann, M.; Drexler, H.G. The NKL-code for innate lymphoid cells reveals deregulated expression of NKL homeobox genes HHEX and HLX in anaplastic large cell lymphoma (ALCL). Oncotarget 2020, 11, 3208-3226. [CrossRef]

22. Nagel, S.; Scherr, M.; MacLeod, R.A.F.; Pommerenke, C.; Koeppel, M.; Meyer, C.; Kaufmann, M.; Dallmann, I.; Drexler, H.G. NKL homeobox gene activities in normal and malignant myeloid cells. PLoS ONE 2019, 14, e0226212. [CrossRef]

23. Nagel, S.; Pommerenke, C.; Meyer, C.; Drexler, H.G. NKL Homeobox gene VENTX is part of a regulatory network in human conventional dendritic cells. Int. J. Mol. Sci. 2021, 22, 5902. [CrossRef]

24. Nagel, S. NKL-Code in Normal and Aberrant Hematopoiesis. Cancers 2021, 13, 1961. [CrossRef]

25. Farlik, M.; Halbritter, F.; Müller, F.; Choudry, F.A.; Ebert, P.; Klughammer, J.; Farrow, S.; Santoro, A.; Ciaurro, V.; Mathur, A.; et al. DNA methylation dynamics of human hematopoietic stem cell differentiation. Cell Stem Cell 2016, 19, 808-822. [CrossRef]

26. Allen, J.D.; Lints, T.; Jenkins, N.A.; Copeland, N.G.; Strasser, A.; Harvey, R.P.; Adams, J.M. Novel murine homeo box gene on chromosome 1 expressed in specific hematopoietic lineages and during embryogenesis. Genes Dev. 1991, 5, 509-520. [CrossRef]

27. Crompton, M.R.; Bartlett, T.J.; MacGregor, A.D.; Manfioletti, G.; Buratti, E.; Giancotti, V.; Goodwin, G.H. Identification of a novel vertebrate homeobox gene expressed in haematopoietic cells. Nucleic Acids Res. 1992, 20, 5661-5667. [CrossRef] [PubMed]

28. Bedford, F.K.; Ashworth, A.; Enver, T.; Wiedemann, L.M. HEX: A novel homeobox gene expressed during haematopoiesis and conserved between mouse and human. Nucleic Acids Res. 1993, 21, 1245-1249. [CrossRef] [PubMed]

29. Manfioletti, G.; Gattei, V.; Buratti, E.; Rustighi, A.; De Iuliis, A.; Aldinucci, D.; Goodwin, G.H.; Pinto, A. Differential expression of a novel proline-rich homeobox gene (Prh) in human hematolymphopoietic cells. Blood 1995, 85, 1237-1245. [CrossRef] [PubMed]

30. Mack, D.L.; Leibowitz, D.S.; Cooper, S.; Ramsey, H.; Broxmeyer, H.E.; Hromas, R. Down-regulation of the myeloid homeobox protein Hex is essential for normal T-cell development. Immunology 2002, 107, 444-451. [CrossRef] [PubMed]

31. Jackson, J.T.; Nasa, C.; Shi, W.; Huntington, N.D.; Bogue, C.W.; Alexander, W.S.; McCormack, M.P. A crucial role for the homeodomain transcription factor Hhex in lymphopoiesis. Blood 2015, 125, 803-814. [CrossRef]

32. Laidlaw, B.J.; Duan, L.; Xu, Y.; Vazquez, S.E.; Cyster, J.G. The transcription factor Hhex cooperates with the corepressor Tle3 to promote memory B cell development. Nat. Immunol. 2020, 21, 1082-1093. [CrossRef]

33. Allen, J.D.; Harris, A.W.; Bath, M.L.; Strasser, A.; Scollay, R.; Adams, J.M. Perturbed development of T and B cells in mice expressing an Hlx homeobox transgene. J. Immunol. 1995, 154, 1531-1542. [PubMed]

34. Migueles, R.P.; Shaw, L.; Rodrigues, N.P.; May, G.; Henseleit, K.; Anderson, K.G.; Goker, H.; Jones, C.M.; de Bruijn, M.F.; Brickman, J.M.; et al. Transcriptional regulation of Hhex in hematopoiesis and hematopoietic stem cell ontogeny. Dev. Biol. 2017, 424, 236-245. [CrossRef] [PubMed]

35. Lewis, K.E. How do genes regulate simple behaviours? Understanding how different neurons in the vertebrate spinal cord are genetically specified. Philos. Trans. R. Soc. Lond. B Biol. Sci. 2006, 361, 45-66. [CrossRef]

36. Hunt, P.; Gulisano, M.; Cook, M.; Sham, M.H.; Faiella, A.; Wilkinson, D.; Boncinelli, E.; Krumlauf, R. A distinct Hox code for the branchial region of the vertebrate head. Nature 1991, 353, 861-864. [CrossRef]

37. Depew, M.J.; Simpson, C.A.; Morasso, M.; Rubenstein, J.L. Reassessing the Dlx code: The genetic regulation of branchial arch skeletal pattern and development. J. Anat. 2005, 207, 501-561. [CrossRef] [PubMed]

38. Streit, A. The cranial sensory nervous system: Specification of sensory progenitors and placodes. In StemBook; Harvard Stem Cell Institute: Cambridge, MA, USA, 2008. [PubMed]

39. Nagel, S.; Pommerenke, C.; Meyer, C.; MacLeod, R.A.F.; Drexler, H.G. Establishment of the TALE-code reveals aberrantly activated homeobox gene PBX1 in Hodgkin lymphoma. PLoS ONE 2021, 16, e0246603. [CrossRef]

40. O'Neil, J.; Look, A.T. Mechanisms of transcription factor deregulation in lymphoid cell transformation. Oncogene 2007, 26, 6838-6849. [CrossRef] [PubMed]

41. Eswaran, J.; Sinclair, P.; Heidenreich, O.; Irving, J.; Russell, L.J.; Hall, A.; Calado, D.P.; Harrison, C.J.; Vormoor, J. The pre-B-cell receptor checkpoint in acute lymphoblastic leukaemia. Leukemia 2015, 29, 1623-1631. [CrossRef]

42. Tomolonis, J.A.; Agarwal, S.; Shohet, J.M. Neuroblastoma pathogenesis: Deregulation of embryonic neural crest development. Cell Tissue Res. 2018, 372, 245-262. [CrossRef] 
43. Quentmeier, H.; Pommerenke, C.; Dirks, W.G.; Eberth, S.; Koeppel, M.; MacLeod, R.A.F.; Nagel, S.; Steube, K.; Uphoff, C.C.; Drexler, H.G. The LL-100 panel: 100 cell lines for blood cancer studies. Sci. Rep. 2019, 9, 8218. [CrossRef]

44. Nagel, S.; Pommerenke, C.; MacLeod, R.A.F.; Meyer, C.; Kaufmann, M.; Fähnrich, S.; Drexler, H.G. Deregulated expression of NKL homeobox genes in T-cell lymphomas. Oncotarget 2019, 10, 3227-3247. [CrossRef]

45. Nagel, S.; Ehrentraut, S.; Meyer, C.; Kaufmann, M.; Drexler, H.G.; MacLeod, R.A. Repressed BMP signaling reactivates NKL homeobox gene MSX1 in a T-ALL subset. Leuk. Lymphoma 2015, 56, 480-491. [CrossRef] [PubMed]

46. Nagel, S.; Kaufmann, M.; Drexler, H.G.; MacLeod, R.A. The cardiac homeobox gene NKX2-5 is deregulated by juxtaposition with BCL11B in pediatric T-ALL cell lines via a novel t(5;14)(q35.1;q32.2). Cancer Res. 2003, 63, 5329-5334. [PubMed]

47. Nagel, S.; Ehrentraut, S.; Tomasch, J.; Lienenklaus, S.; Schneider, B.; Geffers, R.; Meyer, C.; Kaufmann, M.; Drexler, H.G.; MacLeod, R.A. Transcriptional activation of prostate specific homeobox gene NKX3-1 in subsets of T-cell lymphoblastic leukemia (T-ALL). PLoS ONE 2012, 7, e40747. [CrossRef] [PubMed]

48. Nagel, S.; Meyer, C.; Kaufmann, M.; Zaborski, M.; MacLeod, R.A.F.; Drexler, H.G. Aberrant activity of NKL homeobox gene NKX3-2 in a T-ALL subset. PLoS ONE 2018, 13, e0197194. [CrossRef] [PubMed]

49. Hatano, M.; Roberts, C.W.; Minden, M.; Crist, W.M.; Korsmeyer, S.J. Deregulation of a homeobox gene, HOX11, by the t(10;14) in T cell leukemia. Science 1991, 253, 79-82. [CrossRef]

50. MacLeod, R.A.; Nagel, S.; Kaufmann, M.; Janssen, J.W.; Drexler, H.G. Activation of HOX11L2 by juxtaposition with 3'-BCL11B in an acute lymphoblastic leukemia cell line (HPB-ALL) with t(5;14)(q35;q32.2). Genes Chromosomes Cancer 2003, 37, 84-91. [CrossRef]

51. Nagel, S.; Pommerenke, C.; Meyer, C.; MacLeod, R.A.F.; Drexler, H.G. Aberrant expression of NKL homeobox genes HMX2 and HMX3 interferes with cell differentiation in acute myeloid leukemia. PLoS ONE 2020, 15, e0240120. [CrossRef]

52. Brendolan, A.; Ferretti, E.; Salsi, V.; Moses, K.; Quaggin, S.; Blasi, F.; Cleary, M.L.; Selleri, L. A Pbx1-dependent genetic and transcriptional network regulates spleen ontogeny. Development 2005, 132, 3113-3126. [CrossRef]

53. Bernard, O.A.; Busson-LeConiat, M.; Ballerini, P.; Mauchauffé, M.; Della Valle, V.; Monni, R.; Nguyen Khac, F.; Mercher, T.; Penard-Lacronique, V.; Pasturaud, P.; et al. A new recurrent and specific cryptic translocation, $\mathrm{t}(5 ; 14)(\mathrm{q} 35 ; \mathrm{q} 32)$, is associated with expression of the Hox11L2 gene in T acute lymphoblastic leukemia. Leukemia 2001, 15, 1495-1504. [CrossRef]

54. Meijerink, J.P. Genetic rearrangements in relation to immunophenotype and outcome in T-cell acute lymphoblastic leukaemia. Best Pract. Res. Clin. Haematol. 2010, 23, 307-318. [CrossRef]

55. De Keersmaecker, K.; Real, P.J.; Gatta, G.D.; Palomero, T.; Sulis, M.L.; Tosello, V.; Van Vlierberghe, P.; Barnes, K.; Castillo, M.; Sole, X.; et al. The TLX1 oncogene drives aneuploidy in T cell transformation. Nat. Med. 2010, 16, 1321-1327. [CrossRef]

56. Dadi, S.; Le Noir, S.; Payet-Bornet, D.; Lhermitte, L.; Zacarias-Cabeza, J.; Bergeron, J.; Villarèse, P.; Vachez, E.; Dik, W.A.; Millien, C.; et al. TLX homeodomain oncogenes mediate T cell maturation arrest in T-ALL via interaction with ETS1 and suppression of TCR $\alpha$ gene expression. Cancer Cell 2012, 21, 563-576. [CrossRef] [PubMed]

57. Villarese, P.; Lours, C.; Trinquand, A.; Le Noir, S.; Belhocine, M.; Lhermitte, L.; Cieslak, A.; Tesio, M.; Petit, A.; LeLorch, M.; et al. $\mathrm{TCR} \alpha$ rearrangements identify a subgroup of NKL-deregulated adult T-ALLs associated with favorable outcome. Leukemia 2018, 32, 61-71. [CrossRef]

58. Przybylski, G.K.; Dik, W.A.; Grabarczyk, P.; Wanzeck, J.; Chudobska, P.; Jankowski, K.; von Bergh, A.; van Dongen, J.J.; Schmidt, C.A.; Langerak, A.W. The effect of a novel recombination between the homeobox gene NKX2-5 and the TRD locus in T-cell acute lymphoblastic leukemia on activation of the NKX2-5 gene. Haematologica 2006, 91, 317-321.

59. Skerjanc, I.S.; Petropoulos, H.; Ridgeway, A.G.; Wilton, S. Myocyte enhancer factor 2C and Nkx2-5 up-regulate each other's expression and initiate cardiomyogenesis in P19 cells. J. Biol. Chem. 1998, 273, 34904-34910. [CrossRef] [PubMed]

60. Nagel, S.; Meyer, C.; Quentmeier, H.; Kaufmann, M.; Drexler, H.G.; MacLeod, R.A. MEF2C is activated by multiple mechanisms in a subset of T-acute lymphoblastic leukemia cell lines. Leukemia 2008, 22, 600-607. [CrossRef] [PubMed]

61. Homminga, I.; Pieters, R.; Langerak, A.W.; de Rooi, J.J.; Stubbs, A.; Verstegen, M.; Vuerhard, M.; Buijs-Gladdines, J.; Kooi, C.; Klous, P.; et al. Integrated transcript and genome analyses reveal NKX2-1 and MEF2C as potential oncogenes in T cell acute lymphoblastic leukemia. Cancer Cell 2011, 19, 484-497. [CrossRef] [PubMed]

62. Nagel, S.; Venturini, L.; Meyer, C.; Kaufmann, M.; Scherr, M.; Drexler, H.G.; Macleod, R.A. Transcriptional deregulation of oncogenic myocyte enhancer factor 2C in T-cell acute lymphoblastic leukemia. Leuk. Lymphoma 2011, 52, 290-297. [CrossRef]

63. Nagel, S.; Ehrentraut, S.; Tomasch, J.; Quentmeier, H.; Meyer, C.; Kaufmann, M.; Drexler, H.G.; MacLeod, R.A. Ectopic expression of homeobox gene NKX2-1 in diffuse large B-cell lymphoma is mediated by aberrant chromatin modifications. PLoS ONE 2013, 8, e61447. [CrossRef]

64. Le Noir, S.; Ben Abdelali, R.; Lelorch, M.; Bergeron, J.; Sungalee, S.; Payet-Bornet, D.; Villarèse, P.; Petit, A.; Callens, C.; Lhermitte, L.; et al. Extensive molecular mapping of TCR $\alpha / \delta$ - and TCR $\beta$-involved chromosomal translocations reveals distinct mechanisms of oncogene activation in T-ALL. Blood 2012, 120, 3298-3309. [CrossRef]

65. Small, E.M.; Vokes, S.A.; Garriock, R.J.; Li, D.; Krieg, P.A. Developmental expression of the Xenopus Nkx2-1 and Nkx2-4 genes. Mech. Dev. 2000, 96, 259-262. [CrossRef]

66. Manoli, M.; Driever, W. nkx2.1 and nkx2.4 genes function partially redundant during development of the zebrafish hypothalamus, preoptic region, and pallidum. Front. Neuroanat. 2014, 8, 145. [CrossRef]

67. Kusy, S.; Gerby, B.; Goardon, N.; Gault, N.; Ferri, F.; Gérard, D.; Armstrong, F.; Ballerini, P.; Cayuela, J.M.; Baruchel, A.; et al. NKX3.1 is a direct TAL1 target gene that mediates proliferation of TAL1-expressing human T cell acute lymphoblastic leukemia. J. Exp. Med. 2010, 207, 2141-2156. [CrossRef] [PubMed] 
68. Soulier, J.; Clappier, E.; Cayuela, J.M.; Regnault, A.; García-Peydró, M.; Dombret, H.; Baruchel, A.; Toribio, M.L.; Sigaux, F. HOXA genes are included in genetic and biologic networks defining human acute T-cell leukemia (T-ALL). Blood 2005, 106, 274-286. [CrossRef] [PubMed]

69. Tan, Y.; Testa, J.R. DLX Genes: Roles in Development and Cancer. Cancers 2021, 13, 3005. [CrossRef]

70. Sunwoo, J.B.; Kim, S.; Yang, L.; Naik, T.; Higuchi, D.A.; Rubenstein, J.L.; Yokoyama, W.M. Distal-less homeobox transcription factors regulate development and maturation of natural killer cells. Proc. Natl. Acad. Sci. USA 2008, 105, 10877-10882. [CrossRef] [PubMed]

71. Starkova, J.; Gadgil, S.; Qiu, Y.H.; Zhang, N.; Hermanova, I.; Kornblau, S.M.; Drabkin, H.A. Up-regulation of homeodomain genes, DLX1 and DLX2, by FLT3 signaling. Haematologica 2011, 96, 820-828. [CrossRef]

72. Tan, Y.; Timakhov, R.A.; Rao, M.; Altomare, D.A.; Xu, J.; Liu, Z.; Gao, Q.; Jhanwar, S.C.; Di Cristofano, A.; Wiest, D.L.; et al. A novel recurrent chromosomal inversion implicates the homeobox gene Dlx5 in T-cell lymphomas from Lck-Akt2 transgenic mice. Cancer Res. 2008, 68, 1296-1302. [CrossRef]

73. Tan, Y.; Sementino, E.; Xu, J.; Pei, J.; Liu, Z.; Ito, T.K.; Cai, K.Q.; Peri, S.; Klein-Szanto, A.J.; Wiest, D.L.; et al. The homeoprotein Dlx5 drives murine T-cell lymphomagenesis by directly transactivating Notch and upregulating Akt signaling. Oncotarget 2017, 8, 14941-14956. [CrossRef] [PubMed]

74. Tan, Y.; Sementino, E.; Liu, Z.; Cai, K.Q.; Testa, J.R. Wnt signaling mediates oncogenic synergy between Akt and Dlx5 in T-cell lymphomagenesis by enhancing cholesterol synthesis. Sci. Rep. 2020, 10, 15837. [CrossRef]

75. Schleussner, N.; Merkel, O.; Costanza, M.; Liang, H.C.; Hummel, F.; Romagnani, C.; Durek, P.; Anagnostopoulos, I.; Hummel, M.; Jöhrens, K.; et al. The AP-1-BATF and -BATF3 module is essential for growth, survival and TH17/ILC3 skewing of anaplastic large cell lymphoma. Leukemia 2018, 32, 1994-2007. [CrossRef]

76. Crescenzo, R.; Abate, F.; Lasorsa, E.; Tabbo', F.; Gaudiano, M.; Chiesa, N.; Di Giacomo, F.; Spaccarotella, E.; Barbarossa, L.; Ercole, E.; et al. Convergent mutations and kinase fusions lead to oncogenic STAT3 activation in anaplastic large cell lymphoma. Cancer Cell 2015, 27, 516-532. [CrossRef]

77. Nagel, S.; Pommerenke, C.; Meyer, C.; Kaufmann, M.; MacLeod, R.A.F.; Drexler, H.G. Aberrant expression of NKL homeobox gene HLX in Hodgkin lymphoma. Oncotarget 2018, 9, 14338-14353. [CrossRef] [PubMed]

78. Nagel, S.; Uphoff, C.C.; Dirks, W.G.; Pommerenke, C.; Meyer, C.; Drexler, H.G. Epstein-Barr virus (EBV) activates NKL homeobox gene HLX in DLBCL. PLoS ONE 2019, 14, e0216898. [CrossRef] [PubMed]

79. Nagel, S.; Ehrentraut, S.; Meyer, C.; Kaufmann, M.; Drexler, H.G.; MacLeod, R.A. Oncogenic deregulation of NKL homeobox gene MSX1 in mantle cell lymphoma. Leuk. Lymphoma 2014, 55, 1893-1903. [CrossRef] [PubMed]

80. Nagel, S.; Pommerenke, C.; Meyer, C.; Kaufmann, M.; Drexler, H.G.; MacLeod, R.A. Deregulation of polycomb repressor complex 1 modifier AUTS2 in T-cell leukemia. Oncotarget 2016, 7, 45398-45413. [CrossRef] [PubMed]

81. Grocott, T.; Tambalo, M.; Streit, A. The peripheral sensory nervous system in the vertebrate head: A gene regulatory perspective. Dev. Biol. 2012, 370, 3-23. [CrossRef]

82. Saunders, A.; Faiola, F.; Wang, J. Concise review: Pursuing self-renewal and pluripotency with the stem cell factor Nanog. STEM CELLS 2013, 31, 1227-1236. [CrossRef]

83. Das, B.; Pal, B.; Bhuyan, R.; Li, H.; Sarma, A.; Gayan, S.; Talukdar, J.; Sandhya, S.; Bhuyan, S.; Gogoi, G.; et al. MYC Regulates the HIF $2 \alpha$ Stemness Pathway via Nanog and Sox 2 to Maintain Self-Renewal in Cancer Stem Cells versus Non-Stem Cancer Cells. Cancer Res. 2019, 79, 4015-4025. [CrossRef] [PubMed]

84. Mariyath, M.P.M.; Shahi, M.H.; Farheen, S.; Tayyab, M.; Khanam, N.; Ali, A. Novel Homeodomain Transcription Factor Nkx2.2 in the Brain Tumor Development. Curr. Cancer Drug Targets 2020, 20, 335-340. [CrossRef]

85. Habener, J.F.; Kemp, D.M.; Thomas, M.K. Minireview: Transcriptional regulation in pancreatic development. Endocrinology 2005, 146, 1025-1034. [CrossRef]

86. Drexler, H.G.; MacLeod, R.A. Malignant hematopoietic cell lines: In vitro models for the study of anaplastic large-cell lymphoma. Leukemia 2004, 18, 1569-1571. [CrossRef]

87. Drexler, H.G.; Matsuo, Y.; MacLeod, R.A. Malignant hematopoietic cell lines: In vitro models for the study of erythroleukemia. Leuk. Res. 2004, 28, 1243-1251. [CrossRef]

88. Drexler, H.G.; Quentmeier, H.; MacLeod, R.A.; Uphoff, C.C.; Hu, Z.B. Leukemia cell lines: In vitro models for the study of acute promyelocytic leukemia. Leuk. Res. 1995, 19, 681-691. [CrossRef]

89. Drexler, H.G. Leukemia cell lines: In vitro models for the study of chronic myeloid leukemia. Leuk. Res. 1994, 18, 919-927. [CrossRef]

90. Matsuo, Y.; Drexler, H.G. Establishment and characterization of human B cell precursor-leukemia cell lines. Leuk. Res. 1998, 22, 567-579. [CrossRef]

91. Drexler, H.G.; Eberth, S.; Nagel, S.; MacLeod, R.A. Malignant hematopoietic cell lines: In vitro models for double-hit B-cell lymphomas. Leuk. Lymphoma 2016, 57, 1015-1020. [CrossRef] [PubMed]

92. Drexler, H.G.; Pommerenke, C.; Eberth, S.; Nagel, S. Hodgkin lymphoma cell lines: To separate the wheat from the chaff. Biol. Chem. 2018, 399, 511-523. [CrossRef] [PubMed]

93. Drexler, H.G. Malignant hematopoietic cell lines: In vitro models for the study of myelodysplastic syndromes. Leuk. Res. 2000, 24, 109-115. [CrossRef]

94. Drexler, H.G.; Matsuo, Y. Malignant hematopoietic cell lines: In vitro models for the study of multiple myeloma and plasma cell leukemia. Leuk. Res. 2000, 24, 681-703. [CrossRef] 
95. Drexler, H.G.; Matsuo, Y. Malignant hematopoietic cell lines: In vitro models for the study of natural killer cell leukemialymphoma. Leukemia 2000, 14, 777-782. [CrossRef]

96. Carbone, A.; Cesarman, E.; Gloghini, A.; Drexler, H.G. Understanding pathogenetic aspects and clinical presentation of primary effusion lymphoma through its derived cell lines. AIDS 2010, 24, 479-490. [CrossRef]

97. Drexler, H.G.; Ehrentraut, S.; Nagel, S.; Eberth, S.; MacLeod, R.A. Malignant hematopoietic cell lines: In vitro models for the study of primary mediastinal B-cell lymphomas. Leuk. Res. 2015, 39, 18-29. [CrossRef] 